\title{
MIĘDZY TEORIĄ A PRAKTYKĄ: KIERUNKI POLITYKI ZAGRANICZNEJ INDONEZJI W XXI WIEKU ORAZ JEJ POZYCJA W STOSUNKACH MIECDZYNARODOWYCH Z PERSPEKTYWY KONCEPCJI PAŃSTW ŚREDNIEJ RANGI
}

Współcześnie zarówno naukowa, jak i publicystyczna debata o stosunkach międzynarodowych w regionie Azji i Pacyfiku w dużej mierze jest zorientowana na analizę najważniejszych państw tego obszaru, tj. Chińskiej Republiki Ludowej i Stanów Zjednoczonych, w kontekście wzrastającej rywalizacji między nimi.

Mniejszą uwagę w analizach politycznych w regionie poświęca się tzw. państwom średniej rangi ${ }^{1}$ (ang. middle powers) oraz ich znaczeniu dla ewolucji ładu Indo-Pacyfiku² (a tym samym także porządku globalnego), mimo że są jego istotnymi elementami. Państwa średnie definiuje się jako grupę państw o statusie słabszym niż mocarstwowy, ale jednocześnie odgrywające aktywną rolę w polityce międzynarodowej3. Tak sformułowana pozycja tych krajów siła rzeczy powoduje, że są one widocznymi podmiotami w systemie międzynarodowym.

Celem niniejszego artykułu jest przedstawienie koncepcji państw średniej rangi na gruncie nauki o stosunkach międzynarodowych na przykładzie jednego z wiodących państw średnich w regionie - Republiki Indonezji. Ze względu na strategiczne położenie geograficzne, aspiracje do roli politycznego lidera Azji Południowo-

1 W artykule przyjęto tłumaczenia „państwa średnie” i „państwa średniej rangi”.

2 Od momentu objęcia funkcji prezydenta Stanów Zjednoczonych przez Donalda Trumpa w oficjalnych dokumentach rządowych Stanów Zjednoczonych region wcześniej nazywany regionem „Azji i Pacyfiku” zaczął być określany jako region „Indo-Pacyfiku”. Doprowadziło to m.in. do zmiany nazewnictwa amerykańskiego Dowództwa Bojowego z US Pacific Command (USPACOM) na US Indo-Pacific Command (USINDOPACOM), która była podyktowana chęcią większego uwzględnienia Azji Południowej w regionalnych stosunkach międzynarodowych, w dużej mierze ze względu na rosnące znaczenie strategiczne Indii dla polityki zagranicznej Stanów Zjednoczonych. I. Ali, In symbolic nod to India, U.S. Pacific Command changes name, Reuters, https://www.reuters.com/article/us-usa-defense-india/in-symbolic-nod-to-india-us-pacificcommand-changes-name-idUSKCN1IV2Q2 (dostęp: 20.10.2019).

3 A. Włodkowska-Bagan, Środki i metody polityki zagraničnej państw średniej rangi. Casus Polski po 1989 r. [w:] Bezpieczeństwo międsynarodowe. Polska - Europa - swiat, red. A. Włodkowska-Bagan, J. Zając, M. Kaczmarski, Warszawa 2015, s. 295-309. 
-Wschodniej czy potencjał gospodarczy i ludnościowy Indonezja jest klasyfikowana według analityków jako państwo średnie, jednak o rosnącym znaczeniu politycznym w regionie. W pierwszej części artykułu w zarysie została przedstawiona koncepcja państw średnich w stosunkach międzynarodowych oraz sposoby ich definiowania. W drugiej części na wybranych przykładach zostały omówione najważniejsze kierunki polityki zagranicznej Indonezji w XXI wieku, wskazujące na rolę, jaką może odgrywać ten kraj w systemie międzynarodowym.

\section{Państwa średnie w stosunkach międzynarodowych: teoria i praktyka}

Tradycyjnie można wskazać na cztery sposoby definiowania państw średniej rangi: podejście pozycyjne (poprzez czynniki ilościowe, jak np. wielkość PKB), geograficzne (wskazujące na położenie między dwoma mocarstwami), normatywne (odnoszące się do wartości wyznawanych przez te kraje w dyplomacji) oraz behawioralne (wskazanie konkretnych sposobów zachowań w polityce zagranicznej, charakterystycznych dla państw średnich) ${ }^{4}$. Współcześnie popularne jest także odwołanie do teorii konstruktywizmu, według którego pojęcie państw średniej rangi jest „społecznym konstruktem", a jego akceptacja i wdrożenie w życie stanowi odzwierciedlenie stanu intelektualnego elit politycznych oraz społeczeństwa ${ }^{5}$.

Innym podejściem w analizie państw średnich jest zastosowanie teorii ról w stosunkach międzynarodowych. Zgodnie z nią dwoma podstawowymi czynnikami kształtującymi role danego kraju, jakie chce ogrywać w polityce zagranicznej, są: jego pozycja w systemie międzynarodowym oraz tożsamość (zarówno wewnętrzna, jak i postrzeganie przez aktorów zewnętrznych) ${ }^{6}$. W ujęciu przedmiotowym państwo może odgrywać określone role polityczne, ekonomiczne czy ideologiczne, zaś w ujęciu przestrzennym będą to role odgrywane np. na poziomie subregionalnym, regionalnym czy globalnym ${ }^{7}$.

Przywołane rozbieżności definicyjne powodują, że niemożliwe jest stworzenie jednego, powszechnie akceptowanego katalogu krajów klasyfikowanych jako państwa średnie. W regionie Azji i Pacyfiku najczęściej postrzegane w ten sposób są:

4 A. Cooper, R. Higgott, K. Nossal, Relocating middle Powers: Australia and Canada in a Changing World Order, Vancouver 1993, s. 17-21.

5 A. Carr, Is Australia a middle power? A systemic impact approach, „Australian Journal of International Affairs" 2014, vol. 68, no. 1, s. 70-84.

6 J. Zając, Role międzynarodowe państwa średniego - aspekty teoretyczne, „Krakowskie Studia Międzynarodowe" 2013, nr 4, s. 15-27.

7 J. Zając, Teoria ról międzynarodowych [w:] Teorie i podejścia badawcze w nauce o stosunkach miedzynarodowych, red. R. Zięba, S. Bieleń, J. Zając, Warszawa 2015, s. 127-150. 
Korea Południowa, Indonezja, Australia, Tajlandia, Malezja, Filipiny, ale także Wietnam, Singapur, Pakistan, a niekiedy (co należy uznać za błędne) nawet Indie oraz Japonia ${ }^{8}$. Analizując politykę zagraniczną Indonezji jako państwa średniego, odwołano się do trzech kryteriów: 1) pozycyjnych, takich jak PKB, dochód na jednostkę czy wielkość sił zbrojnych oraz poziom wydatków na zbrojenia (podejście „realistyczne"); 2) percepcyjnych - postrzegania samego siebie jako państwa średniego (element konstruktywistyczny); 3) ról na arenie międzynarodowej, jakie Indonezja chce odgrywać w XXI wieku (teoria ról) 9 .

\section{Indonezja jako państwo średniej rangi}

W literaturze naukowej zgodnie przyjmuje się, bez względu na kontekst definicyjny, że Indonezję zarówno w przestrzeni regionalnej, jak i globalnej można klasyfikować jako państwo średnie. Odnosząc się do czynników policzalnych (pozycyjnych), Indonezja na tle innych państw średnich wyróżnia się terytorium i populacją. Ze względu na populację (ok. $267 \mathrm{mln}$ obywateli według danych z 2018 r.) Indonezja jest czwartym najludniejszym krajem świata. Pod względem PKB mierzonego nominalnie jest klasyfikowana jako „państwo rozwijające się” lub „mocarstwo wschodzace" i zajmuje 16. miejsce na świecie z wielkościa gospodarki przekraczająca 1 bln USD ${ }^{10}$, zaś pod względem PKB per capita Indonezja z dochodami na poziomie ok. 3900 USD rocznie plasuje się poza pierwszą setką rankingów ${ }^{11}$. Pod względem geograficznym znajduje się w strategicznym punkcie pomiędzy dwoma kontynentami - Azją i Australia, a także dwoma oceanami - jest położona na Oceanie Indyjskim i Pacyfiku.

Odnosząc się do rocznych wydatków na zbrojenia, które można uznać za jeden $\mathrm{z}$ przejawów politycznego $\mathrm{i}$ wojskowego potencjału w skali regionalnej i globalnej, według corocznego raportu Stockholm International Peace Research Institute (SIPRI), Indonezja w 2018 r. zajęła 26. miejsce na świecie, przeznaczając na ten cel

8 A. Sari, C. Thies, A Role Theory Approach to Middle Powers: Making Sense of Indonesia's Place in the International System, „Contemporary Southeast Asia” 2018, vol. 40, no. 3, s. 397-421.

9 M. Karim, Middle power, status-seeking and role conceptions: the cases of Indonesia and South Korea, „Australian Journal of International Affairs” 2018, no. 72, vol. 4, s. 343-363.

${ }^{10}$ Gross domestic product 2018, World Bank, https://databank.worldbank.org/data/download/ GDP.pdf (dostęp: 24.10.2019).

11 Uwzględniając parytet siły nabywczej, Indonezja już obecnie zajmuje 7. miejsce na świecie pod względem mierzonej w ten sposób wielkości gospodarki. Uwzględniając poziom wzrostu gospodarczego, Indonezja do 2030 r. ma szansę stać się jedną z dziesięciu największych gospodarek na świecie. Gross national income per capita 2018. Atlas method and PPP, World Bank, https:// databank.worldbank.org/data/download/GNIPC.pdf (dostęp: 25.10.2019). 
7,6 mld USD, co jest porównywalne do Kuwejtu i Norwegii12. W regionie Azji Południowo-Wschodniej więcej na zbrojenia wydaje Singapur (10,8 mld USD, $3,1 \%$ rocznego PKB). Porównując przytoczone dane, należy podkreślić, że Indonezja przeznacza rocznie na siły zbrojne ok. 1\% rocznych wydatków Stanów Zjednoczonych (ok. 649 mld USD) i ok. 3\% wydatków Chińskiej Republiki Ludowej (ok. 250 mld USD według szacunków SIPRI) ${ }^{13}$. Indonezyjskie Siły Zbrojne (TNI - Tentara Nasional Indonesia) liczące ponad 430 tys. aktywnych żołnierzy są największymi siłami zbrojnymi w Azji Południowo-Wschodniej. Jednak ich rzeczywisty potencjał, zwłaszcza wojsk lądowych, jest oceniany krytycznie z perspektywy możliwości obrony terytorium kraju, co jest spotęgowane rozpiętością geograficzną Indonezji1 ${ }^{14}$.

Zatem na gruncie czynników policzalnych i geograficznych można przypisać Indonezji atrybuty „średniego zasięgu” - choć jest najważniejszym podmiotem w Azji Południowo-Wschodniej, to znacznie odbiega od głównych mocarstw (Chin i USA) na płaszczyźnie gospodarczej oraz politycznej, zachowując przy tym duży potencjał rozwoju ekonomicznego i militarnego.

Odnosząc się do konstruktywistycznego sposobu definiowania państw średnich, historyczne doświadczenia Indonezji, zwłaszcza okresu kolonializmu, wpłynęły po 1945 r. na obranie przez nią dwóch podstawowych kierunków polityki zagranicznej, opartych na aktywnej roli w stosunkach międzynarodowych, co znalazło swoje odzwierciedlenie w Konstytucji Indonezji z 1945 r. Po pierwsze, celem stało się zakwestionowanie wszelkich przejawów kolonializmu, a Indonezja zaczęła aspirować do miana reprezentanta i obrońcy państw rozwijających się oraz byłych kolonii ${ }^{15}$. Po drugie, w preambule konstytucja stanowi, że celem rządu jest „udział w porządku międzynarodowym opartym na wolności, wiecznym pokoju i społecznej sprawiedliwości" ${ }^{16}$. Ówczesny wiceprezydent Indonezji Mohammad Hatta scharakteryzował podstawową zasadę polityki zagranicznej Indonezji jako politykę „,wolną i aktywną” (bebas aktif), co stało się aksjomatem indonezyjskiej dyplomacji zarówno po $1965 \mathrm{r}$. i objęciu rządów przez generała Suharto, jak i po 1998 r. i transformacji demokratycznej ${ }^{17}$. Jak wskazuje Anak Agung Banyu Perwita: „Historycznie, główne korzenie

12 Trends in world military expenditure 2018, Stockholm International Peace Research Institute, https:// www.sipri.org/sites/default/files/2019-04/fs_1904_milex_2018_0.pdf (dostęp: 28.10.2019).

13 Ibidem.

14 R. Sukma, Indonesia's Security Outlook, Defence Policy and Regional Cooperation [w:] Asia Pacific Countries' Security Outlook and its Implication for the Defence Sector, 2010, no. 5, s. 3-24, http://www. nids.mod.go.jp/english/publication/joint_research/series5/pdf/5-1.pdf (dostęp: 4.11.2019).

15 The 1945 Constitution of the State of the Republic of Indonesia, http://biblioteka.sejm.gov.pl/ wp-content/uploads/2016/06/Indonezja_ang_010716.pdf (dostęp: 20.10.2019).

16 Ibidem.

17 M. Williams, Indonesia, Islam, and the International Political Economy: Clash Or Cooperation?, New York 2017, s. 83-84. 
bebas-aktif jako podstawowej zasady indonezyjskiej polityki zagranicznej po uzyskaniu niepodległości wywodzą się z preambuły do konstytucji (...). Pomimo tego, że nie określa ona szczegółowo charakterystyki polityki zagranicznej kraju, reprezentuje główne jej wartości”'18.

Krytyka spuścizny kolonializmu widoczna była zwłaszcza w czasach rządów Sukarno, a Indonezja stała się jednym z założycieli Ruchu Państw Niezaangażowanych, będąc w 1955 r. gospodarzem w czasie Konferencji Solidarności Afryki i Azji w Bandungu na Jawie Zachodniej ${ }^{19}$. W okresie rządów Suharto podstawowym kierunkiem polityki zagranicznej kraju był region Azji Południowo-Wschodniej. Polityka ta opierała się na multilateralizmie, jednak w ramach Stowarzyszenia Narodów Azji Południowo-Wschodniej (ASEAN - Association of Southeast Asian Nations) ${ }^{20}$.

Po transformacji ustrojowej i zakończeniu autorytarnych rządów generała Suharto w 1998 r. Indonezja stopniowa sama zaczęła siebie definiować jako państwo średniej rangi. Moch Karim podkreśla ambiwalentny stosunek do samego pojęcia „państwa średniego” indonezyjskich elit politycznych, według których postrzeganie siebie w ten sposób miałoby być przejawem ograniczenia własnego potencjału ${ }^{21}$. Co interesujące, podobne argumenty podnoszone są także $w$ innych państwach średniej rangi, np. w Australii ${ }^{22}$.

Przełomowy zarówno dla ogólnego rozwoju polityki zagranicznej Indonezji po 1998 r., jak i samego odwoływania się do koncepcji państw średniej rangi był okres rządów prezydenta Susilo Bambang Yudhoyono w latach 2004-2014. Było to związane $\mathrm{z}$ faktem, że w okresie prezydentury tego polityka sformułowano takie zasady polityki zagranicznej, jak „dyplomacja we wszystkich kierunkach” czy „tysiące przyjaciól, zero wrogów"23, oparte na liberalnym internacjonalizmie.

W okresie prezydentury Joko Widodo w Strategicznym planie Ministerstwa Spraw Zagranicznych na lata 2015-2019 (Kementerian Luar Negeri Republik Indonesia 2015) dyplomacja Indonezji jako państwa średniego stała się oficjalnym

18 A.A. Banyu Perwita, Indonesia and the Muslim World: Between Islam and Secularism in the Foreign Policy of Soebarto and Beyond, Copenhagen 2007, s. 8.

19 N. Mišković, Introduction [w:] The Non-Aligned Movement. Delhi-Bandung - Belgrade, eds. N. Boškovska, H. Fischer-Tine, N. Mišković, New York 2014, s. 1-19.

20 M. Beeson, The Middle Power Moment: A New Basis for Cooperation between Indonesia and Australia [w:] Indonesia's Ascent. Power, Leadership, and the Regional Order, eds. A. Habir, L. Sebastian, C. Roberts, New York 2015, s. 224-244.

21 M. Karim, Middle power...

22 C. Ungerer, The "Middle Power” Concept in Australian Foreign Policy, „Australian Journal of Politics\&History" 2007, vol. 53, no. 4, s. 538-551.

23 E. Laksmana, Pragmatic Equidistance. How Indonesia Manages Its Great Power Relations [w:] China, The United States, and the Future of Southeast Asia: U.S.-China Relations, ed. D. Denoon, New York 2017, s. 113-135. 
elementem strategii politycznej państwa ${ }^{24}$. Kementerian Luar Negeri Republik Indonesia 2015 wyznacza osiem podstawowych kierunków polityki zagranicznej państwa, z czego dwoma głównymi są: wzmocnienie dyplomacji morskiej w kontekście utrzymania suwerenności Indonezji oraz wzmocnienie pozycji Indonezji jako lidera Stowarzyszenia Narodów Azji Południowo-Wschodniej. Trzecim z kolei jest już „wzmocnienie pozycji Indonezji jako państwa średniej rangi w stosunkach międzynarodowych, co jednoznacznie wskazuje, w jaki sposób współcześnie Indonezja definiuje siebie w polityce międzynarodowej ${ }^{25}$.

$\mathrm{Na}$ podstawie oficjalnych dokumentów państwowych i rzeczywistych działań na arenie międzynarodowej, odwołując się do teorii ról w stosunkach międzynarodowych jako typologii dla państw średnich, a także prac M. Karima i C. Thiesa, można wymienić sześć podstawowych ról, jakie w swojej polityce zagranicznej stara się realizować Indonezja: 1) lider Stowarzyszenia Narodów Azji Południowo-Wschodniej, 2) promotor demokracji, 3) stabilizator systemu międzynarodowego, 4) głos państw rozwijających się, 5) „dobry obywatel międzynarodowy”, 6) państwo wspierajace multilateralizm ${ }^{26}$.

W kontekście tych ról zarys polityki zagranicznej Indonezji można analizować na trzech płaszczyznach: na poziomie subregionalnym ${ }^{27}$ (jako lidera ASEAN), regionalnym (w kontekście ewolucji systemu międzynarodowego regionu Azji i Pacyfiku w okresie rosnącej rywalizacji chińsko-amerykańskiej) oraz globalnym (w ramach takich organizacji, jak np. G-20). Należy przy tym pamiętać, że jest to podział uproszczony, bowiem w rzeczywistości w ramach ASEAN Indonezja realizuje cele na wszystkich trzech poziomach, zaś ewolucja systemu międzynarodowego ma charakter nie tylko regionalny, typowy dla Indo-Pacyfiku, ale też globalny.

${ }^{24}$ Kementerian Luar Negeri Republik Indonesia 2015, https://kemlu.go.id (dostęp: 12.11.2019).

25 Odwołanie się do koncepcji middle power w polityce zagranicznej ma prowadzić do sytuacji, w której „dyplomacja państwa średniej rangi doprowadzi do wzmocnienia pozycji Indonezji jako regionalnego mocarstwa o selektywnym zaangażowaniu globalnym”. Ibidem.

26 M. Karim, Middle power...; A. Sari, C. Thies, A Role Theory Approach...

27 Pojęcie poziomu subregionalnego zostało przywołane dla rozróżnienia dwóch płaszczyzn działań w ramach integracji regionalnej w Azji Południowo-Wschodniej oraz - w szerszej perspektywie - w regionie Azji i Pacyfiku. Jedną z charakterystycznych cech regionu Azji i Pacyfiku jest jego rozpiętość geograficzna, co powoduje, że w jego skład wchodzą subregiony, tj. Azja Północno-Wschodnia, Azja Południowa, Azja Centralna, Oceania czy właśnie Azja Południowo-Wschodnia, co daje możliwość integracji zarówno w węższym (subregionalnym), jak i szerszym (poziom Azji i Pacyfiku) zakresie. D. Shambaugh, International Relations in Asia. A Multidimensional Analysis [w:] International Relations of Asia-Pacific, eds. D. Shambaugh, M. Yahuda, Plymouth 2014, s. $26-45$. 


\section{Indonezja jako lider Stowarzyszenia Narodów Azji Południowo-Wschodniej}

Indonezja jest najbardziej zaludnionym państwem Azji Południowo-Wschodniej, największą gospodarką w ramach ASEAN i jedynym członkiem tego zrzeszenia w ramach G-20, zaś jej terytorium to ponad $40 \%$ całego terytorium państw organizacji - z naturalnych przyczyn kraj ten po II wojnie światowej był predestynowany do miana lidera regionu ${ }^{28}$.

Po obaleniu Sukarno, objęciu władzy przez generała Suharto oraz zakończeniu polityki Konfrontasi, której symbolem stał się konflikt z Malezją w latach 1963-1966, Indonezja zaczęła dążyć do stabilizacji sytuacji wewnętrznej poprzez integrację regionalna. Poprzez przyjęcie Deklaracji z Bangkoku z 1967 r. stała się kluczowym graczem, stojącym za powstaniem Stowarzyszenia Narodów Azji Południowo-Wschodniej, w skład którego pierwotnie weszło pięć państw, tj. oprócz Indonezji, Singapur, Malezja, Filipiny, Tajlandia ${ }^{22}$.

W okresie rządów generała Suharto ASEAN było przede wszystkim skoncentrowane na ochronie suwerenności państw członkowskich, zapewnieniu bezpieczeństwa, ograniczeniu wpływu komunizmu oraz wpływów mocarstw w Azji Południowo-Wschodniej. Było to związane z realizacją celów autorytarnego reżimu Suharto, a zostało wyrażone w takich porozumieniach, jak Deklaracja o strefie pokoju, wolności i neutralności (ZOPFAN - Declaration of Zone of Peace, Freedom and Neutrality) czy Traktat o przyjaźni i współpracy (TAC - Treaty of Amity and Cooperation) z 1976 r. ${ }^{30}$, które narzuciły zasady funkcjonowania ASEAN oparte na dialogu, współpracy i zasadzie nieingerencji w sprawy wewnętrzne pozostałych krajów ${ }^{31}$. Istotna rola Indonezji w przyjęciu powyższych porozumień powodowała, że od samego początku nosiła ona miano „lidera” organizacji bądź też primus inter pares, a więc pierwszego wśród równych w ramach ASEAN ${ }^{32}$.

28 C. Roberts, E. Widyaningsih, Indonesian Leadership in ASEAN: Mediation, Agency and Extra-Regional Diplomacy [w:] Indonesia's Ascent. Power..., s. 265.

${ }^{29}$ W 1984 r. do organizacji dołączyło Brunei, zaś w latach 1995-1999 - Wietnam, Laos, Kambodża oraz Mjanma. Obecnie w skład ASEAN wchodzi 10 państw. Potencjalnym kandydatem do członkostwa w ASEAN może być w przyszłości Timor Wschodni. O znaczeniu Indonezji dla powołania i funkcjonowania tej organizacji może świadczyć m.in. fakt, że siedziba samej organizacji i jej sekretariatu jest położona w Dżakarcie. M. Grabowski, Rywalizacja cąy integracja? Procesy i organizacje integracyjne w regionie Azji i Pacyfiku na pręetomie XX i XXI wieku, Kraków 2015, s. 197-223.

30 Treaty of Amity and Cooperation in Southeast Asia Indonesia, Association of Southeast Asian Nations, http://asean.org/treaty-amity-cooperation-southeast-asia-indonesia-24-february-1976 (dostęp: 26.10.2019).

31 S. Simon, ASEAN and Southeast Asia: Remaining Relevant [w:] International Relations..., s. 194-208.

32 D.F. Anwar, ASEAN and Indonesia: Some Reflections, „Asian Journal of Political Science” 1997, vol. 5 , no. 1 , s. $20-34$. 
Z perspektywy polityki zagranicznej Indonezji i jej pozycji w ASEAN kluczowe wydarzenia rozegrały się pod koniec lat 90. Wówczas doszło do znacznego osłabienia statusu Indonezji w stosunkach międzynarodowych, zwłaszcza w wyniku Azjatyckiego Kryzysu Finansowego z lat 1997-1998, w wyniku którego obrót gospodarczy Indonezji zmalał między 1997 a 1998 r. o 13\%. Innymi z istotnych przyczyn były także: problemy transformacji ustrojowej, niestabilność wewnętrzna Indonezji, wynikająca m.in. z niepodległości Timoru Wschodniego ${ }^{33}$ oraz problem terroryzmu na początku XXI wieku, czego najbardziej dotkliwym przejawem były zamachy na wyspie Bali z 2002 r., w czasie których śmierć poniosło 202 ludzi, w tym 88 obywateli Australiii ${ }^{34}$. Wspomniane czynniki spowodowały, że lata 1998-2004 i prezydentury Jusufa Habibe (1998-1999), Abdurrahmana Wahida (1999-2001) i Megawati Sukarnoputri (2001-2004) odznaczały się spadkiem roli Indonezji w ASEAN ze względu na konieczność koncentracji na problemach wewnętrznych i brak jednoznacznej wizji prowadzenia dyplomacji w ramach ASEAN. Sytuacja uległa znacznej poprawie w okresie rządów Susilo Bambang Yudhoyono (2004-2014) oraz Joko Widodo (2014-) ${ }^{35}$.

Ewolucja systemu międzynarodowego i upadek ładu dwubiegunowego na przełomie lat 80. i 90. wpłynęły na rozwój ASEAN w kierunku organizacji integracyjnej o ekonomicznym charakterze ${ }^{36}$. W 1992 r. podjęto decyzję o utworzeniu Strefy Wolnego Handlu ASEAN (AFTA - ASEAN Free Trade Agreement) do 2008 r. (ostatecznie zrealizowane w 2003 r.) i rozszerzeniu preferencji handlowych funkcjonujących w regionie od lat 70. i 80. Jak twierdzi jednak Ralf Emmers, w ramach samego ASEAN, pomimo pozycji Indonezji jako największej gospodarki zrzeszenia, historycznie z reguły to inne kraje, takie jak Singapur, Malezja i Tajlandia, były wiodące w dziedzinie tworzenia kolejnych rozwiązań gospodarczych wraz z AFTA oraz Wspólnotą Gospodarczą ASEAN ${ }^{37}$. Dlatego Indonezja, pomimo ostatecznej akceptacji tych porozumień, miała ambiwalentny stosunek zarówno do podpisania AFTA w 1992 r., jak i umów handlowych (AFTA+) zawartych przez ASEAN z państwami trzecimi, takimi jak Chiny, Japonia, Korea Południowa, Indie czy Nowa Zelandia ${ }^{38}$. W odniesieniu do tego R. Emmers indonezyjską pozycję

33 P. Szafraniec, Misje pokojowe ONZ w Timorze Wschodnim, „Forum Politologiczne” 2010, t. 11, s. $455-501$.

34 A. Vickers, A History of Modern Indonesia, New York 2013, s. 184-196.

35 R. Kusumaningrang, The Roots and Evolution of Indonesia's Middle Power Activism, „Indonesian Quarterly" 2017, vol. 45, no. 2, s. 152-179.

36 D. Weatherbee, International Relations in Southeast Asia. The Struggle for Autonomy, New York 2009, s. 201-219.

37 R. Emmers, Indonesia's role in ASEAN: A case of incomplete and sectorial leadership, „Pacific Review" 2014, vol. 27, no. 4, s. 543-562.

38 A Artner, Role of Indonesia in the Evolution of ASEAN, „The Journal of East Asian Affairs” 2017, vol. 31, no. 1, s. 1-38. 
w ramach ASEAN określa mianem ,sektorowego przywództwa”, skupiającego się przede wszystkim na kwestiach politycznych i bezpieczeństwa ${ }^{39}$. W XXI wieku politykę Indonezji w ramach ASEAN można analizować na trzech płaszczyznach: 1) kreowanie rozwiązań instytucjonalnych i propagowania wartości, tj. demokracja oraz prawa człowieka; 2) działania w dziedzinie bezpieczeństwa, w szczególności w odniesieniu do sporu na Morzu Południowochińskim; 3) wpływanie na kierunki strategiczne ASEAN oraz dbanie o jej pozycję międzynarodową.

\section{Rola Indonezji w kształtowaniu wartości oraz instytucjonalizacji w ramach ASEAN}

Ze względu na stabilizację sytuacji gospodarczej oraz przyjęcie nowej polityki antyterrorystycznej, która okazała się skutecznym instrumentem w zwalczaniu terroryzmu religijnego, dopiero końcówka prezydentury Megawati Sukarnoputriego umożliwiła powrót do aktywnej polityki Indonezji w ramach ASEAN. W 2003 r. Indonezja, korzystając z pełnienia funkcji rotacyjnego przewodniczącego ASEAN, zaproponowała stworzenie Wspólnoty Bezpieczeństwa ASEAN jako jednego z trzech filarów ASEAN, obok Wspólnoty Ekonomicznej oraz Wspólnoty Społeczno-Kulturowej ${ }^{40}$.

Pomimo że nawet obecnie kondycja demokracji w Indonezji, zwłaszcza w porównaniu do państw zachodnich, jest przedmiotem krytyki ze strony instytucji międzynarodowych i think tanków, tj. Freedom House, sama promocja wartości demokratycznych w celu tworzenia przyjaznego otoczenia międzynarodowego stała się jednym z podstawowych kierunków polityki zagranicznej kraju ${ }^{41}$. W zamyśle Indonezji konsekwencja utworzenia Wspólnoty Bezpieczeństwa ASEAN (która ostatecznie powstała pod nazwą Wspólnota Polityczna i Bezpieczeństwa) miało być większe uwzględnienie roli praw człowieka i demokratycznych wartości poprzez powołanie Międzyrządowej Komisji Praw Człowieka ASEAN (AICHR - ASEAN Intergovernmental Commission on Human Rights). Ostatecznie ze względu na niezadowolenie niedemokratycznych członków organizacji Wspólnotę Polityczną i Bezpieczeństwa utworzono w ograniczonym charakterze, rezygnując zarazem z innego z indonezyjskich pomysłów - stworzenia Sił Pokojowych ASEAN ${ }^{42}$. W 2004 r.

${ }^{39}$ R. Emmers, Indonesia's role...

40 C. Roberts, E. Widyaningsih, Indonesian Leadership..., s. 267-271.

${ }^{41}$ Krajowy raport Freedom House klasyfikuje Indonezję jako państwo „częściowo wolne” (partly free), wskazując z jednej strony na osiagnięcia transformacji ustrojowej kraju po 1998 r., z drugiej - krytykując niezmienne problemy pełnej demokratyzacji Indonezji, związane z systemowa korupcja czy dyskryminacją i przemocą wobec mniejszości. Freedom in the World 2019. Indonesia, Freedom House, https://freedomhouse.org/report/freedom-world/2019/indonesia (dostęp: 13.12.2019).

${ }^{42}$ V. Bernard, Is It Time for a Peacekeeping Force for ASEAN, The Asia Foundation, https://asiafoundation.org/2016/02/03/is-it-time-for-a-peacekeeping-force-for-asean/ (dostęp: 4.11.2019). 
na spotkaniu ministerialnym ASEAN (AMM - ASEAN Ministerial Meeting), po przyjęciu Bali Concord II i zaakceptowaniu pomysłu integracji także w sprawach politycznych oraz bezpieczeństwa, zaakceptowano utworzenie AICHR, co ostatecznie zostało zrealizowane w 2009 r. ${ }^{43}$ Trzy lata później przyjęto Deklarację Praw Człowieka ASEAN (ASEAN Human Rights Declaration) ${ }^{44}$. Indonezja miała również kluczowy wpływ na przyjęcie Karty ASEAN (The ASEAN Charter) w czasie szczytu w Singapurze w 2007 r. $^{45}$

Przywołanie polityki Indonezji w dziedzinie promocji wartości demokratycznych szeroko wykracza poza samo znaczenie tychże (jakkolwiek promowanie podobnego systemu politycznego ma konkretne cele polityczne związane z tworzeniem sprzyjającego państwu otoczenia międzynarodowego), ponieważ wskazuje na podstawowe problemy Indonezji w polityce wobec ASEAN ${ }^{46}$. Po pierwsze, większość systemów politycznych państw Stowarzyszenia Narodów Azji Południowo-Wschodniej (Laos, Kambodża, Wietnam, Tajlandia, Mjanma, Brunei) jest klasyfikowana jako ustroje niedemokratyczne. Po drugie, Indonezja respektuje podstawową zasadę funkcjonowania ASEAN, czyli nie ingeruje w sprawy wewnętrzne innych państw, przyjmując, że wartości ustrojowe można promować jedynie w formie dialogu i współpracy, ale nie przymusowo. Wynika to także z koncepcji tzw. wartości azjatyckich. Koncepcja ta kwestionuje uniwersalizm ukształtowanych w kulturze zachodniej praw człowieka czy praw politycznych, wskazując na równorzędny, zasadniczo odmienny, powstały w azjatyckim kręgu kulturowym system wartości społeczno-politycznych, typowy dla społeczeństw tego regionu, także w Azji Południowo-Wschodniej ${ }^{47}$. Tym samym, pomimo że Indonezja promuje się na kraj skutecznej transformacji demokratycznej i wzór umiarkowanego państwa muzułmańskiego o stabilnym systemie społecznym i politycznym, jej polityka w okresie prezydentury Susilo Bambang Yudhoyono w tym zakresie nie przyniosła daleko idących, realnych efektów.

W związku z powyższym o ile w okresie rządów Suharto formuła działania ASEAN jako organizacji opartej na szeroko rozumianej zasadzie nieingerencji

43 ASEAN Intergovernmental Commission on Human Rights (AICHR), Association of Southeast Asian Nations, https://asean.org/asean-political-security-community/asean-intergovernmental-commission-on-human-rights-aichr/ (dostęp: 10.10.2019).

${ }^{44}$ ASEAN Human Rights Declaration and the Phnom Penh Statement on the Adoption of the ASEAN Human Rights Declaration (AHRD), Association of Southeast Asian Nations, https://www.asean. org/storage/images/ASEAN_RTK_2014/6_AHRD_B ooklet.pdf (dostęp: 12.10.2019).

${ }^{45}$ F. Heiduk, Indonesia in ASEAN: Regional Leadership Between Ambition and Ambiguity, „SWP Research Papers" 2016, issue 6, s. 5-38, https://www.swp-berlin.org/fileadmin/contents/products/research_pap ers/2016RP06_hdk.pdf (dostęp: 17.11.2019).

46 K.P. Erawan, Indonesia, Supporting Democracy Aborad: An Assesment of Leading Powers, Freedom House, https://freedomhouse.org/sites/default/files/FH_Demo_Reports_Indonesia_final.pdf (dostęp: 21.09.2019).

47 G. Langguth, Asian values revisited, „Asia Europe Journal” 2013, no. 1, s. 25-42. 
w sprawy wewnętrzne innych państw, zapewniającej stabilny system bezpieczeństwa bezpośrednio zgadzała się z linią polityczną Indonezji w polityce regionalnej, o tyle współcześnie jest jednym z elementów ograniczających możliwości Indonezji i - jak pisze Mike Beeson - jedną z przyczyn „frustracji” indonezyjskich elit politycznych ${ }^{48}$.

Jakkolwiek ASEAN wciąż jest definiowane jako centrum polityki zagranicznej Indonezji, część obserwatorów twierdzi, że w kontekście jej pozycji jako najbardziej dynamicznie rozwijającego się państwa w regionie z czasem organizacja ta może przestać stanowić gremium potrzebne dla realizacji jego polityki. Zdaniem niektórych już teraz ASEAN ogranicza Indonezję na arenie międzynarodowej. Jest to też jedna z przyczyn, dla których w okresie rządów Joko Widodo doszło do relatywnego spadku zainteresowania promowaniem wartości demokratycznych Indonezji w regionie ${ }^{49}$.

\section{Indonezja a spór na Morzu Południowochińskim}

W pierwszym okresie funkcjonowania ASEAN, a więc w okresie zimnej wojny, gdy przeważała w organizacji tematyka bezpieczeństwa, Indonezja starała się odgrywać rolę stabilizatora w potencjalnych sporach między jej członkami. Po stabilizacji sytuacji w Indochinach i rozszerzeniu członkostwa ASEAN o kolejne państwa podstawowym zagrożeniem w regionie stał się konflikt terytorialny na Morzu Południowochińskim i spór między wieloma członkami ASEAN a Chińską Republiką Ludową o wyspy znajdujące się na tym akwenie ${ }^{50}$.

Jeśli chodzi o interesy Indonezji w sporze na Morzu Południowochińskim, to można je rozpatrywać na trzech płaszczyznach. Po pierwsze, spór stanowi zagrożenie dla bezpieczeństwa w regionie w wypadku wybuchu konfliktu terytorialnego z udziałem państw regionu lub aktorów zewnętrznych. Po drugie, może stać się źródłem konfliktów w ramach państw ASEAN. Po trzecie, Indonezja dąży do ochrony własnego archipelagu na spornym akwenie ze względu na nieporozumienia z Chinami ${ }^{51}$.

Od początku lat 90. Indonezja aktywnie dąży do rozwiązania konfliktu na gruncie współpracy w ramach istniejących porozumień multilateralnych: relacji ASEAN z Chinami oraz instytucjami pochodnymi ASEAN, przede wszystkim w ramach Forum Regionalnego ASEAN (ARF - ASEAN Regional Forum) oraz Szczytu Azji

\footnotetext{
48 M. Beeson, The Middle Power...

49 M. Karim, Middle power...

50 E. Laksmana, Drifting towards Dynamic Equilibrium: Indonesia's South China Sea Policy under Yudhoyono [w:] Aspirations with Limitations: Indonesia's Foreign Affairs under Susilo Bambang Yudhoyono, eds. U. Fionna. D. Negara. D. Simandjuntak, Singapore 2018, s. 153-175.

51 Ibidem.
} 
Wschodniej (EAS - East Asia Summit) ${ }^{52}$. W tym celu organizowała warsztaty o zarządzaniu potencjalnymi konfliktami na Morzu Południowochińskim, które zostały zainagurowane w 1990 r. na Bali, a także wspierała przyjęcie Deklaracji o postępowaniu stron na Morzu Południowochińskim (Declaration on the Conduct of Parties in the South China Sea) w 2002 r. ${ }^{53}$, która jednak nie miała wiażącego prawnie charakteru. Obecnie, w obliczu wzrostu znaczenia sporu na Morzu Południowochińskim, Indonezja dąży do zawarcia rzeczywistego regionalnego kodeksu postępowania pomiędzy ASEAN i Chinami w celu załagodzenia sytuacji ${ }^{54}$.

To, że konflikt ten może mieć znaczenie dla spójności samego ASEAN, odzwierciedla sytuacja z 2012 r., gdy rotacyjne przewodnictwo ASEAN przypadło Kambodży, blisko współpracującej z Chinami. Wówczas po raz pierwszy w historii ASEAN w czasie szczytu w Phnom Penh nie opublikowano oficjalnego komunikatu państw ze względu na opozycję Kambodży wobec deklaracji potępiającej chińskie działania na Morzu Południowochińskim, którą wspierały zwłaszcza Filipiny i Wietnam jako aktywne strony sporu. Minister spraw zagranicznych Indonezji Marty Natalegawa przez kilka następnych dni aktywną dyplomacja załagodził sytuację i doprowadził ostatecznie do ogłoszenia oficjalnego stanowiska ${ }^{55}$. Poza oparciem się na dialogu i współpracy z wykorzystaniem mechanizmów wielostronnych w ramach instytucji tożsamych ASEAN Indonezja odwołuje się do prawa międzynarodowego, zasadniczo popierając wyrok Stałego Trybunału Arbitrażowego w Hadze z 2016 r., uznającego brak podstaw prawnych do chińskich roszczeń w procesie wytoczonym przez Filipiny ${ }^{56}$.

W polityce prowadzonej na Morzu Południowochińskim Indonezja dąży do roli mediatora $\mathrm{w}$ konflikcie i nie jest podmiotem występującym z jakimikolwiek roszczeniami terytorialnymi w tym sporze. W rzeczywistości od ogłoszenia w 1993 r. roszczeń chińskich poprzez wyznaczenie tzw. linii dziewięciu kresek na spornym $a_{k w e n i e}{ }^{57}$ dochodzi do stałych nieporozumień pomiędzy oboma krajami. Indonezja

52 J. Cochrane, Indonesia, Long on Sidelines, Starts to Confront China's Territorial Claims, „New York Times", https://www.nytimes.com/2017/09/10/world/asia/indonesia-south-china-sea-military-buildup.html (dostęp: 21.09.2019).

53 M. Pietrasiak, Konflikt o archipelagi na Morzu Poludniowochinskim i perspektyny jego uregulowania [w:] Międzynarodowe studia polityczne i kulturowe wobec wyzwań wspótczesności, red. T. Domański, Lódź 2016, s. 261-274.

54 M. Beeson, The Middle Power...

55 D. Weatherbee, Re-Assessing Indonesia's Role in the South China Sea, „ISEAS Perspective” 2016, no. 18, s. 1-13, https://www.iseas.edu.sg/images/pdf/ISEAS_Perspective_2016_18.pdf (dostęp: 18.11.2019).

56 Ibidem.

57 Chiny objęły tą linią jako własne bogate w surowce naturalne i istotne z perspektywy rybołówstwa tereny morskie w okolicach Wysp Natuna należące prawnie do tzw. wyłącznej strefy ekonomicznej (EEZ - Exclusive Economic Zone) Indonezji. 
stoi jednak na stanowisku, że nie ma oficjalnego sporu o charakterze terytorialnym pomiędzy nią a Chinami ${ }^{58}$.

Niemniej w 2016 r. na wodach okalających wyspy doszło do wielu incydentów w postaci nielegalnej obecności chińskich łodzi rybackich oraz interwencji chińskiej straży przybrzeżnej. Ponieważ prezydent Joko Widodo zapowiadał walkę z nielegalnym połowem ryb na indonezyjskich akwenach, a Indonezja definiuje się od 2014 r. jako „globalna oś morska” (Global Maritime Axis), działania Chińczyków wywołały daleko idącą reakcję Indonezji. W dokumentach indonezyjskich zmieniono nazwę wód pobliskich Wyspom Natuna na Morze Północnonatuńskie ${ }^{59}$. Ponadto pod koniec 2018 r. otwarto bazę wojskową na jednej z natuńskich wysp ${ }^{60}$. Zdaniem obserwatorów w efekcie tych kroków częściowo spadło znaczenie współpracy wielostronnej (przede wszystkim w ASEAN, ARF oraz na linii ASEAN-Chiny) dla polityki rządu Widodo wobec sporu na Morzu Południowochińskim, która stała się bardziej unilateralna. Państwo to bowiem zaczęło podejmować indywidualne działania w celu zwiększenia ochrony de facto spornej części akwenu pomiędzy Indonezją a Chinami ${ }^{61}$.

W rzeczywistości, choć Indonezja przyjęła bardziej autonomiczną postawę w zakresie ochrony indonezyjskiej wyłącznej strefy ekonomicznej, to wspiera w dalszym ciagu proces dialogu i współpracy w sporze między ASEAN i Chinami ${ }^{62}$. Działania Chińczyków wskazują jednak na problemy Indonezji w spełnianiu swej roli mediatora w tym konflikcie.

\section{Indonezja jako stabilizator systemu międzynarodowego w obliczu rywalizacji chińsko-amerykańskiej?}

Indonezja w obliczu rosnącej rywalizacji chińsko-amerykańskiej i alternatywnych wizji rozwoju stosunków międzynarodowych w regionie zmuszona jest do sformu-

58 A. Agustiyara, P. Meyer, A. Nurmandi, Indonesia's swift securitization of the Natuna Islands: how Jakarta countered China's claims in the South China Sea, „Asian Journal of Political Science” 2019, vol. 27 , issue 1 , s. $70-87$.

59 Indonezja żmienia naz̧we cześsi Morza Południowochińskiego, Centrum Studiów Polska-Azja, http://www.polska-azja.pl/indonezja-zmienia-nazwe-czesci-morza-poludniowochinskiego (dostęp: 19.11.2019).

${ }^{60}$ Indonesia opens military base on edge of South China Sea to 'deter security threats', South China Morning Post, https://www.scmp.com/news/asia/southeast-asia/article/2178741/indonesia-opensmilitary-base-edge-south-china-sea-deter (dostęp: 21.10.2019).

${ }^{61}$ R.A. Supriyanto, Out of Its Comfort Zone: Indonesia and the South China Sea, „Asia Policy” 2016, no. 21, s. 21-28.

62 A. Connelly, Indonesia in the South China Sea: Going it alone, Lowy Institute for International Policy, https://www.lowyinstitute.org/sites/default/files/documents/Connelly $\% 2 \mathrm{C} \% 20$ Indonesia\%20in\%20t he\%20South\%20China\%20Sea.pdf (dostęp: 21.09.2019). 
łowania własnego stanowiska wobec odbywającej się ewolucji ładu międzynarodowego. W XXI wieku, w szczególności od początku prezydentury Susilo Bambang Yudhoyono, wzorem innych państw średnich, jak np. Australia, korzystając z relatywnie stabilnej sytuacji międzynarodowej, Indonezja doprowadziła do wzmocnienia wzajemnych relacji z oboma partnerami, co jest zgodne z zasadami jej wolnej i otwartej polityki zagranicznej.

Z jednej strony od 2017 r. Chiny są dla Indonezji ważne jako jej główny partner handlowy (równocześnie najważniejszy partner handlowy ASEAN), po 2005 r. także strategiczny w relacjach polityczno-ekonomicznych i w inwestycjach zagranicznych, zaś po utworzeniu w 2016 r. Azjatyckiego Banku Inwestycji Infrastrukturalnych dodatkowo sa potencjalnie istotnym państwem z perspektywy pomocy rozwojowej.

Z drugiej strony Stany Zjednoczone pozostaja istotne z perspektywy ekonomicznej (drugi po Chinach kierunek eksportu), a także są bardzo ważnym partnerem w ramach współpracy w dziedzinie bezpieczeństwa, zwłaszcza po zamachach z 11 września oraz na wyspie Bali z 2002 r. ${ }^{63}$ Evan Laksmana nazywa relacje Indonezji z USA i Chinami „,pragmatyczną równoległością”. Rizal Sukma, opisując strategiczne położenie Indonezji, stwierdził w 2012 r., że „Dżakarta nie może pozwolić sobie na zmierzenie się w jedną ze stron. Indonezja potrzebuje obu: Stanów Zjednoczonych i Chin, jako przyjaciół i partnerów, i nie chciałaby, by oba supermocarstwa zostały rywalami" "64.

Za przejaw wypośrodkowanej polityki zagranicznej wobec Chin oraz USA należy uznać starania Indonezji w drugiej dekadzie XXI wieku o sformułowanie niezależnej strategii politycznej ASEAN wobec regionu Indo-Pacyfiku, która odzwierciedlałaby koncepcję „dynamicznej równowagi”, jaką ma się rządzić ten region, z uwzględnieniem roli organizacji jako jednego z jego centrów w myśl zasady „centralności ASEAN” (ASEAN Centrality). Oparcie się w polityce regionalnej na „centralności ASEAN” ma prowadzić do sytuacji, w której regionalne procesy polityczne sa prowadzone i definiowane przez mechanizmy ASEAN oraz jej instytucji pochodnych $^{65}$.

W 2013 r. M. Natalegawa sformułował wizję utworzenia Traktatu o przyjaźni i współpracy Indo-Pacyfiku na wzór Traktatu o przyjaźni i współpracy ASEAN z 1976 r., jednak o szerszym geograficznie charakterze ${ }^{66}$. Następczyni Natalegawy,

63 E. Fels, Shifting Power in Asia-Pacific? The Rise of China, Sino-US Competition and Regional Middle Power Allegiance, Springer International, [b.m.] 2016, s. 705-731.

64 E. Laksmana, Pragmatic Equidistance..., s. 123-133.

65 A. Domachowska, Analiza strategicznej narracji ASEAN-u, „Athenaeum. Polskie Studia Politologiczne" 2017, vol. 54, s. 23-37.

66 D. Weatherbee, Indonesia, ASEAN, and the Indo-Pacific Cooperation Concept, 2019, „ISEAS Perspective" 2019, no. 47, s. 1-9, https://www.iseas.edu.sg/images/pdf/ISEAS_Perspective_ 2019_47.pdf (dostęp: 21.11.2019). 
Retno Marsudi na szczycie Azji Wschodniej w 2018 r. ogłosiła koncepcję współpracy Indo-Pacyfiku (Indo-Pacific Cooperation Concept), która miała mniej wiążący charakter, ale podobny cel, tj. zachowanie centralności ASEAN w architekturze regionalnej i oparcie współpracy w całym regionie Indo-Pacyfiku na transparentności, inkluzyjności, szacunku do prawa międzynarodowego oraz regułach postępowania pierwotnie wypracowanych i przyjętych w ASEAN ${ }^{67}$.

Ostatecznie, w dużej mierze dzięki zabiegom Indonezji, w czerwcu 2019 r. ogłoszono dokument ASEAN's Outlook on the Indo-Pacific. W myśl tego dokumentu ASEAN w zgodzie z założeniami poprzednich indonezyjskich koncepcji podkreśla znaczenie dla porządku regionalnego takich elementów, jak: otwartość, zaangażowanie oparte na przyjętych regułach postępowania, zwrócenie uwagi na instytucjonalne mechanizmy kierowane przez ASEAN czy dialog oraz współpraca. W literaturze podnosi się, że Indonezja była wiodącym państwem dążącym do przyjęcia dokumentu oraz odzwierciedla on jej aktualne stanowisko wobec ewolucji porządku międzynarodowego w regionie. Wiodący badacz stosunków regionalnych Amitav Acharya twierdzi, że o ile sam dokument nie ma wiążącej mocy, o tyle stanowi typowy przykład funkcjonowania ASEAN jako podmiotu budującego regionalny konsensus poprzez przyjęcie stanowiska umiarkowanego względem strategii politycznych zarówno Stanów Zjednoczonych, jak i $\mathrm{Chin}^{68}$.

Zdaniem R. Sukmy z perspektywy Indonezji podstawowymi celami w omawianym obszarze są: zachowanie znaczenia ASEAN, utrzymanie centralności ASEAN dla stosunków międzynarodowych w regionie, a także zachowanie jedności ASEAN i strategicznej autonomii Azji Południowo-Wschodniej w obliczu rosnącej presji mocarstw zewnętrznych ${ }^{69}$.

\section{Indonezja jako aktor globalny}

Indonezja definiuje się jako „regionalne mocarstwo” o „selektywnym zaangażowaniu w wymiarze globalnym". Na tej płaszczyźnie mają zastosowanie role: lidera ASEAN, promotora państw rozwijających się, promotora demokracji oraz państwa wspierającego procesy wielostronne, a także „dobrego obywatela międzynarodowego" ${ }^{\text {"70 }}$.

67 D. Scott, Seeking Stability: Indonesia seeks to maintain balance in tense Indo-Pacific crossroads, „Strategic Vision" 2019, vol. 8, no. 40, s. 20-25.

68 A. Acharya, Why ASEAN'S Indo-Pacific outlook matters, Asia-Europe Institute, https://aei. um.edu.my/why-asean-rsquo-s-indo-pacific-outlook-matters (dostęp: 21.11.2019).

${ }_{69}$ R. Sukma, Indonesia, ASEAN and shaping the Indo-Pacific idea, East Asia Forum, https://www. eastasiaforum.org/2019/11/19/indonesia-asean-and-shaping-the-indo-pacific-idea (dostęp: 29.11.2019).

${ }^{70}$ E. Laksmana, Inndonesia's Rising Regional and Global Profile: Does Size Really Matter?, „Contemporary Southeast Asia” 2011, vol. 33, no. 2, s. 157-182. 
Należy odnotować, że rolę lidera regionu Azji Południowo-Wschodniej, a zarazem przedstawiciela państw rozwijających się Indonezja od 2008 r. może realizować w wymiarze globalnym jako jedyny członek ASEAN w ramach G-2071. W 2009 r. z inicjatywy Indonezji utworzono Grupę Kontaktową G-20 ASEAN, zaś w 2011 r. przyjęto Deklarację z Bali o wspólnocie ASEAN w globalnej społeczności narodów (Bali Concord III), której celem było m.in. wzmocnienie zaangażowania ASEAN w ramach G-20 oraz innych organizacji i instytucji wielostronnych w regionie i na świecie ${ }^{72}$.

Jako przykład roli „dobrego obywatela międzynarodowego” można podać aktywność Indonezji w Organizacji Narodów Zjednoczonych. W latach 2007-2008 państwo to po raz trzeci zostało wybrane jako niestały członek Rady Bezpieczeństwa ONZ. Ponownie pełniło tę funkcję w latach 2019-2020 $0^{73}$. Innym z przejawów zaangażowania w ramach ONZ jest uczestnictwo w Misjach Pokojowych ONZ, gdzie Indonezja jest jednym z najbardziej zaangażowanych państw z liczbą personelu sięgająca niemal 3 tys. Wiąże się to ze wspomnianym konstytucyjnym odwołaniem się do działań na rzecz wolności, pokoju i sprawiedliwości oraz sformułowaną na jego podstawie zasada , wolnej i aktywnej” polityki zagranicznej kraju, czego przejawem jest partycypacja w międzynarodowych środkach pomocy pokojowej i humanitarnej ${ }^{74}$.

W zakresie promocji demokracji o charakterze ponadregionalnym należy zwrócić uwage, że w 2008 r. z inicjatywy Indonezji utworzono Forum Demokratyczne na Bali (Bali Democratic Forum) jako centrum dyskusji na temat praw człowieka ${ }^{75}$. Ma to charakter wykraczający poza samą Azję Południowo-Wschodnią, ponieważ w roli uczestników i obserwatorów występują nie tylko państwa regionu Azji i Pacyfiku, ale także przedstawiciele m.in. Unii Europejskiej czy Unii Afrykańskiej ${ }^{76}$.

Innym z przejawów aktywności Indonezji o charakterze globalnym było utworzenie w 2013 r. nieformalnego zrzeszenia państw MIKTA (akronim od nazw

71 A. Habir, Y. Hermawan, Indonesia and International Institutions: Treading New Territory [w:] Indonesia's Ascent. Power..., s. 181-194.

72 Bali Declaration on ASEAN Community in a Global Community of Nations. "Bali Concord III" Plan of Action 2013-2017, Association of Southeast Asian Nations, https:/www.asean.org/ wp-content/uploads/images/2013/other_documents/POA $\% 20$ of $\% 20$ Bali $\% 20$ Concord $\% 20$ III\%20_final_.pdf (dostęp: 11.10.2019).

${ }^{73}$ Indonesian Membership on the UN Security Council, Ministry of Foreign Affairs of the Republic of Indonesia, https://kemlu.go.id/portal/en/read/147/halaman_list_lainnya/indonesian-membership-on-the-un-security-council (dostęp: 29.10.2019).

74 D. Capie, Indonesia as an Emerging Peacekeeping Power: Norm Revisionist or Pragmatic Provider?, „Contemporary Southeast Asia” 2016, vol. 38, no. 1, s. 1-27.

75 A. Grzywacz, Retoryka i praktyka: polityka Indonezjï wobec Zachodu, „Annales Universitatis Mariae Curie-Skłodowska, Lublin-Polonia, Sectio K. Politologia” 2019, vol. 26, no. 1, s. 7-21.

76 A. Azra, Indonesia's Middle Power Public Diplomacy: Asia and Beyond [w:] Understanding Public Diplomacy in East Asia. Middle Powers in a Troubled Region, eds. J. Melissen, Y. Sohn, New York 2015, s. $131-155$. 
uczestniczących państw: Meksyk, Indonezja, Korea Południowa, Turcja, Australia) w celu poprawy globalnego zarządzania i współpracy na szczeblu ministrów spraw zagranicznych państw w takich dziedzinach, jak energetyka, operacje pokojowe, zwalczanie terroryzmu, handel czy zrównoważony rozwój $j^{77}$. Pomimo różnic społeczno-kulturowych i luźnej struktury operacyjnej państwa te łączy członkostwo w grupie G-20, podobny poziom wielkości gospodarek oraz status „państw średnich" w stosunkach międzynarodowych. Indonezja pozostaje również aktywnym członkiem innych politycznych organizacji wielostronnych, takich jak np. Organizacja Współpracy Islamskiej.

\section{Podsumowanie}

Artykuł nie aspiruje do miana całościowego opisu polityki zagranicznej Indonezji w XXI wieku; nie poruszono szerzej wątków polityki zagranicznej w dziedzinie integracji gospodarczej czy istotnej dla tego kraju współpracy w zwalczaniu międzynarodowego terroryzmu. Celem niniejszej pracy był opis podstawowych kierunków polityki zagranicznej Indonezji w XXI wieku, w szczególności w okresie prezydentur Susilo Bambang Yudhoyono oraz Joko Widodo, w odniesieniu do koncepcji państw średniej rangi w stosunkach międzynarodowych.

Jak wykazano, Indonezja współcześnie definiuje swoją pozycję w systemie międzynarodowym jako państwo średnie. Za logiczne uznano więc odwołanie do koncepcji teoretycznych związanych z tym pojęciem. Powołując się na teorię ról, prace M. Karima, a także deklaracje i praktykę polityczną kolejnych indonezyjskich administracji, można odnotować takie role odgrywane przez Indonezję w XXI wieku, jak: lider ASEAN, promotor demokracji, głos państw rozwijających się, stabilizator systemu międzynarodowego, „dobry obywatel międzynarodowy” i państwo wspierające multilateralizm, rozpatrując je na trzech płaszczyznach: subregionalnej, regionalnej oraz globalnej.

W odniesieniu do ASEAN można mówić o tzw. sektorowym przywództwie, które skupia się na kwestiach politycznych i bezpieczeństwa, sprowadza się do polityki w dziedzinie instytucjonalizacji i promocji wartości tożsamych Indonezji oraz działań stabilizacyjnych, zwłaszcza w kontekście sporu na Morzu Południowochińskim. Przykładem skutecznej na gruncie instytucjonalnym polityki w zakresie promowania rozwiązań w ramach ASEAN był istotny wkład w kształtowaniu politycznego komponentu Wspólnoty ASEAN. W przypadku konfliktu na Morzu Południowochińskim jest to działanie mediacyjne oparte na współpracy multilateralnej poprzez ASEAN i fora pokrewne, przede wszystkim ARF.

A. Cooper, MIKTA and the Global Projection of Middle Powers: Toward a Summit of Their Own?, „Global Summitry” 2015, vol. 1, issue 1, s. 95-114. 
Na poziomie regionu Indo-Pacyfiku należy podkreślić, że mimo istotnych różnic w programie politycznym Susilo Bambang Yudhoyono i Joko Widodo obaj prezydenci w badanym okresie realizowali politykę w myśl zasady wolnej i otwartej polityki zagranicznej oraz chęci osiagnięcia w regionie Indo-Pacyfiku dynamicznej równowagi między Chinami a Stanami Zjednoczonymi. Jako stabilizator systemu Indonezja z jednej strony doprowadziła do wzmocnienia bilateralnych relacji z oboma mocarstwami w kwestiach gospodarczych i bezpieczeństwa, z drugiej proponowane w ramach ASEAN pomysły administracji Joko Widodo dotyczace sformułowania autonomicznej strategii wobec Indo-Pacyfiku jako trzeciej drogi między strategiami Chin i USA można uznać za spójną kontynuację tych przedstawianych w okresie prezydentury Susilo Bambang Yudhoyono.

W odniesieniu do płaszczyzny ponadregionalnej czy globalnej warto zwrócić uwagę na przywołaną dystynkcję między „tradycyjnymi” a „wschodzącymi” państwami średnimi - o ile Indonezja stara się odgrywać aktywną rolę w polityce globalnej, czego przejawem jest dyplomacja w ramach ONZ czy innych organizacji o charakterze wielostronnym, o tyle mają one charakter stricte drugorzędny względem działań w Azji Południowo-Wschodniej czy szerzej - w regionie Indo-Pacyfiku.

\title{
SUMMARY
}

\author{
BETWEEN THEORY AND PRACTICE: \\ DIRECTIONS OF INDONESIA'S FOREIGN POLICY \\ IN THE TWENTY-FIRST CENTURY AND ITS STATUS \\ IN INTERNATIONAL RELATIONS FROM THE PERSPECTIVE \\ OF THE MIDDLE POWER CONCEPT
}

The aim of this paper is to provide a description and an analysis of Indonesian foreign policy in the twenty-first century as a middle power in international relations. While middle powers are a relevant part of scholarly discourse in the study of international relations, there is considerable confusion as to how to define such states. Because of that, the role theory in international relations has been adopted in an analysis of the foreign policy of Indonesia, which is one of the most dynamically developing states in the world. According to this approach, the six main roles of Indonesia in contemporary international relations can be outlined: its role as a regional leader in Southeast Asia, as a promoter of democracy, as a voice of developing states, as a 'stabiliser' within the international system, as a "good international citizen," and as a state supporting multilateral processes. Those roles can be realized on three levels: the subregional, the regional, and the global. 